\title{
RAGAM MEDIA TANAM DAN PUPUK ORGANIK CAIR (POC) TERHADAP PERTUMBUHAN VEGETATIF BIBIT KELAPA SAWIT (Elaeis guineensis Jacq) DI PEMBIBITAN AWAL
}

\author{
Safi'i \\ Alumnus Program Studi Budidaya Perkebunan, Fakultas Pertanian dan Peternakan, Universitas Tjut Nyak \\ Dhien, Medan 20123, Sumatera Utara, Indonesia. \\ Yunida Berliana* \\ Program Studi Agroteknologi, Fakultas Pertanian dan Peternakan, Universitas Tjut Nyak Dhien, Medan \\ 20123, Sumatera Utara, Indonesia. Email: yd66berliana@gmail.com \\ Tengku Boumedine Hamid Zulkifli \\ Program Studi Agroteknologi, Fakultas Pertanian dan Peternakan, Universitas Tjut Nyak Dhien, Medan \\ 20123, Sumatera Utara, Indonesia.
}

\begin{abstract}
Abstrak
Penelitian ini bertujuan untuk mengkaji penggunaan ragam media tanam dan Pupuk Organik Cair (POC) terhadap pertumbuhan vegetatif bibit kelapa sawit (Elaeis guineensis Jacq) di pembibitan awal. Metode yang digunakan dalam penelitian ini adalah Rancangan Acak Kelompok (RAK) faktorial terdiri dari dua factor yaitu : faktor pertama: pemberian ragam media tanam 3 taraf: $\mathbf{M}_{0}=$ topsoil $100 \%, \mathrm{M}_{1}=$ pupuk kandang ayam $30 \%+$ abu sekam padi $30 \%+$ topsoil $40 \%, \mathrm{M}_{2}=$ kompos $30 \%+$ abu sekam padi $30 \%+$ topsoil $40 \%$. Faktor kedua: pemberian POC 4 taraf: $\mathrm{P}_{0}=$ tanpa POC, $\mathrm{P}_{1}=\mathrm{POC} 10 \mathrm{ml} / \mathrm{l}$ air, $\mathrm{P}_{2}=\mathrm{POC} 20 \mathrm{ml} / 1$ air, $\mathrm{P}_{3}=\mathrm{POC} 30 \mathrm{ml} / \mathrm{l}$ air. Interaksi ragam media tanam dan POC terhadap pertumbuhan vegetative tanaman kelapa sawit (Elaeis guineensis Jacq) di pembibitan awal berpengaruh tidak nyata pada parameter pengamatan yakni tinggi tanaman, diameter batang, bobot basah dan bobot kering tanaman, namun berpengaruh nyata terhadap luas daun.
\end{abstract}

Kata Kunci: kelapa sawit, media tanam, pupuk organik cair

\section{PENDAHULUAN}

Kelapa sawit adalah tanaman penghasil minyak paling tinggi produktivitasnya. Dari kelapa sawit bukan hanya diperoleh minyak untuk keperluan pangan tetapi dapat dibuat untuk keperluan industri lainnya. Keunggulan kelapa sawit cukup banyak, biaya produksi murah, produksi/hektar tinggi (4-6 ton minyak/ha/tahun) dan umur ekonomi panjang (25-30 tahun) (Lubis, 1992).

Dalam usaha membudidayakan kelapa sawit masalah pertama yang dihadapi oleh pengusaha atau petani yang bersangkutan adalah tentang pengadaan bibit. Kualitas bibit sangat menentukan produksi akhir komoditas ini (Sianturi, 1992).

Berdasarkan penelitian di Sumatera Utara, unsur-unsur hara yang berpengaruh positif terhadap pertumbuhan dan produksi kelapa sawit adalah nitrogen $(\mathrm{N})$, fosfor $(\mathrm{P})$, kalium $(\mathrm{K})$, magnesium $(\mathrm{Mg})$, serta unsur hara mikro boron (B) (Sastrosayono, 2008).

Media tumbuh merupakan salah satu unsur penting dalam menunjang pertumbuhan tanaman, karena sebagian besar unsur hara yang dibutuhkan tanaman dipasok melalui media tumbuh, selanjutnya diserap oleh akar dan digunakan untuk pertumbuhan tanaman (Kusmarwiyah et al., 2011).

Kompos, pupuk kandang dan abu sekam padi merupakan hasil dari limbah organik pertanian. Menurut Susanto, (2006), kompos merupakan proses biologi oleg mikroorganisme secara terpisah atau bersama-sama dalam menguraikan bahan organik menjadi semacam humus. Pemberian 5 ton pupuk kompos pada lahan pertanian dapat meningkatkan pertumbuhan tanaman.

Pada penelitian Nasaruddin et al., (2011) bahwa pemberian Pupuk Organik Cair (POC) sebanyak 30 $\mathrm{ml} /$ bibit kakao memberikan hasil yang baik pada tanaaman kakao. Demikian juga menurut Hantu, (2013) bahwa pemberian POC pada tanaman perkebunan sebanyak $20 \mathrm{ml} /$ liter air dapat memberikan hasil yang baik bagi peningkatan pertumbuhan tanaman.

Tujuan penelitian ini mengetahui pengaruh ragam media tanam dan pupuk organik cair (POC) terhadap pertumbuhan vegetatif bibit kelapa sawit (Elaeis guineensis Jacq) di pembibitan awal.

\section{METODE}

\section{Waktu dan Tempat Penelitian}

Penelitian dilaksanakan di Desa Karang Rejo Kecamatan Medan Polonia Medan pada Juni sampai September 2015.

\section{Bahan dan Alat}

Bahan yang digunakan dalam penelitian ini adalah: topsoil, sekam padi, polibag $5 \mathrm{~kg}$ ukuran lebar 25 cm ketebalan 0,15 mm, benih tanaman kelapa sawit D x P keluaran Marihat, Siantar, Pupuk Organik Cair (POC) Hantu Jantan. Alat-alat yang digunakan adalah paranet $80 \%$, cangkul, gembor, label nama, timbangan analitik,alat tulis, plastik, ember, meteran, kalkulator, pompa air. 


\section{Metode Penelitian}

Penelitian ini dilakukan dengan menggunakan Rancangan Acak Kelompok (RAK) faktorial dengan dua faktor yaitu faktor pertama pemberian ragam media tanam 3 taraf : $\mathbf{M}_{0}=$ topsoil $100 \%, \mathrm{M}_{1}=$ pupuk kandang ayam $30 \%$ + abu sekam padi $30 \%$ + topsoil $40 \%, \mathrm{M}_{2}=$ kompos $30 \%+$ abu sekam padi $30 \%+$ topsoil $40 \%$. Faktor kedua: pemberian POC 4 taraf: $\mathrm{P}_{0}=\tan$ a $\mathrm{POC}$, $\mathrm{P}_{1}=\mathrm{POC} 10 \mathrm{ml} / 1$ air, $\mathrm{P}_{2}=$ POC $20 \mathrm{ml} / \mathrm{l}$ air dan $\mathrm{P}_{3}=$ POC $30 \mathrm{ml} / \mathrm{l}$ air. Hasil penelitian ini dianalisis menggunakan model statistik sebagai berikut :

$$
\mathrm{Y}_{\mathrm{ijk}}=\mu+\tau_{\mathrm{i}}+\alpha_{\mathrm{j}}+\beta_{\mathrm{k}}+(\alpha \beta)_{\mathrm{jk}}+\varepsilon_{\mathrm{ijk}}
$$

Data hasil pengamatan dianalisis dengan uji $\mathrm{F}$, apabila dalam uji statistik data diperoleh signifikan maka pengujian dilanjutkan uji DMRT (Duncan Multiple Range Test) (Gomez \& Gomez, 2007).

\section{HASIL DAN PEMBAHASAN Tinggi Bibit (cm)}

Hasil sidik ragam diperoleh bahwa perlakuan media tanam dan pupuk organik cair serta interaksi keduanya berpengaruh tidak nyata terhadap tinggi bibit sawit (Tabel 1).

Tabel 1. Hubungan tinggi dengan interaksi perlakuan ragam media tanam dan pupuk organik cair pada tanaman kelapa sawit umur 11 MST.

\begin{tabular}{cccccc}
\hline Perlakuan & $\mathrm{P}_{0}$ & $\mathrm{P}_{1}$ & $\mathrm{P}_{2}$ & $\mathrm{P}_{3}$ & Rataan \\
\hline $\mathrm{M}_{0}$ & 14,63 & 14,57 & 14,73 & 14,80 & 14,68 \\
$\mathrm{M}_{1}$ & 15,43 & 16,00 & 15,60 & 14,00 & 15,26 \\
$\mathrm{M}_{2}$ & 14,60 & 14,27 & 14,30 & 14,87 & 14,51 \\
\hline Rataan & 14,89 & 14,94 & 14,88 & 14,56 & \\
\hline
\end{tabular}

Keterangan: angka-angka yang diikuti huruf yang sama pada baris atau kolom yang sama menujukkan berbeda tidak nyata pada taraf 5\% menggunakan DMRT.

Pada Tabel 1, dapat dilihat bahwa perlakuan media tanam berpengaruh tidak nyata terhadap tinggi bibit sawit dimana perlakuan tertinggi $M_{1}(15,26 \mathrm{~cm})$ diikuti $\mathrm{M}_{0}(14,68 \mathrm{~cm})$ dan $\mathrm{M}_{2}(14,51 \mathrm{~cm})$. Perlakuan pupuk organik cair (POC) berpengaruh tidak nyata terhadap tinggi bibit sawit dimana perlakuan tertinggi $\mathrm{P}_{1}$ $(14,94 \mathrm{~cm})$ diikuti $\mathrm{P}_{0}(14,89 \mathrm{~cm}), \mathrm{P}_{2}(14,88 \mathrm{~cm})$ dan $\mathrm{P}_{3}$ $(14,56 \mathrm{~cm})$. Interaksi perlakuan media tanam dan pupuk organik cair berpengaruh tidak nyata terhadap tinggi bibit sawit dengan perlakuan tertinggi $\mathrm{M}_{1} \mathrm{P}_{0}(16,00 \mathrm{~cm})$.

\section{Luas Daun $\left(\mathrm{cm}^{2}\right)$}

Hasil sidik ragam diperoleh bahwa perlakuan media tanam dan pupuk organik cair serta interaksi keduanya berpengaruh nyata terhadap luas daun bibit sawit (Tabel 2).

Tabel 2. Hubungan luas daun dan interaksi perlakuan ragam media tanam dan pupuk organik cair pada tanaman kelapa sawit umur 11 MST.

\begin{tabular}{cccccc}
\hline Perlakuan & $\mathrm{P}_{0}$ & $\mathrm{P}_{1}$ & $\mathrm{P}_{2}$ & $\mathrm{P}_{3}$ & Rataan \\
\hline $\mathrm{M}_{0}$ & $16,40 \mathrm{a}$ & $19,08 \mathrm{a}$ & $19,57 \mathrm{a}$ & $17,78 \mathrm{a}$ & $18,21 \mathrm{a}$ \\
$\mathrm{M}_{1}$ & $26,75 \mathrm{a}$ & $24,55 \mathrm{a}$ & $29,69 \mathrm{a}$ & $21,20 \mathrm{a}$ & $25,55 \mathrm{c}$ \\
$\mathrm{M}_{2}$ & $19,94 \mathrm{a}$ & $20,04 \mathrm{a}$ & $34,59 \mathrm{a}$ & $19,09 \mathrm{a}$ & $23,42 \mathrm{~b}$ \\
\hline Rataan & $21,03 \mathrm{~b}$ & $21,22 \mathrm{~b}$ & $27,95 \mathrm{c}$ & $19,36 \mathrm{a}$ & \\
\hline
\end{tabular}

Keterangan: angka-angka yang diikuti huruf yang sama pada baris atau kolom yang sama menujukkan berbeda tidak nyata pada taraf 5\% menggunakan DMRT.
Pada Tabel 2, dapat dilihat bahwa perlakuan media tanam berpengaruh nyata terhadap luas daun bibit sawit dimana perlakuan $\mathrm{M}_{1}\left(25,55 \mathrm{~cm}^{2}\right)$ berbeda nyata dengan $\mathrm{M}_{2}\left(23,42 \mathrm{~cm}^{2}\right)$ dan $\mathrm{M}_{0}\left(18,21 \mathrm{~cm}^{2}\right)$. Perlakuan pupuk organik cair (POC) berpengaruh nyata terhadap luas daun bibit sawit dimana perlakuan $\mathrm{P}_{2}\left(27,95 \mathrm{~cm}^{2}\right)$ berbeda nyata dengan $\mathrm{P}_{1}\left(21,22 \mathrm{~cm}^{2}\right), \mathrm{P}_{0}\left(21,03 \mathrm{~cm}^{2}\right)$ dan $\mathrm{P}_{3}\left(19,36 \mathrm{~cm}^{2}\right)$. Interaksi perlakuan media tanam dan pupuk organik cair berpengaruh nyata terhadap luas daun bibit sawit dengan perlakuan tertinggi $\mathrm{M}_{2} \mathrm{P}_{2}\left(34,59 \mathrm{~cm}^{2}\right)$.

\section{Diameter Batang (mm)}

Hasil sidik ragam diperoleh bahwa perlakuan media tanam dan pupuk organik cair serta interaksi keduanya berpengaruh tidak nyata terhadap diameter batang bibit sawit (Tabel 3).

Tabel 3. Hubungan diameter batang dengan interaksi perlakuan ragam media tanam dan pupuk organik cair pada tanaman kelapa sawit umur 11 MST.

\begin{tabular}{crrrrl}
\hline Perlakuan & $\mathrm{P}_{0}$ & $\mathrm{P}_{1}$ & $\mathrm{P}_{2}$ & $\mathrm{P}_{3}$ & Rataan \\
\hline $\mathrm{M}_{0}$ & 6,77 & 5,50 & 6,57 & 6,50 & 6,33 \\
$\mathrm{M}_{1}$ & 6,40 & 6,97 & 6,10 & 5,57 & 6,26 \\
$\mathrm{M}_{2}$ & 6,30 & 5,77 & 6,00 & 5,53 & 5,90 \\
\hline Rataan & 6,49 & 6,08 & 6,22 & 5,87 & \\
\hline
\end{tabular}

Keterangan: angka-angka yang diikuti huruf yang sama pada baris atau kolom yang sama menujukkan berbeda tidak nyata pada taraf 5\% menggunakan DMRT.

Pada Tabel 3, dapat dilihat bahwa perlakuan media tanam berpengaruh tidak nyata terhadap diameter batang bibit sawit dimana perlakuan tertinggi $\mathbf{M}_{0}(6,33$ $\mathrm{mm})$ diikuti $\mathrm{M}_{1}(6,26 \mathrm{~mm})$ dan $\mathbf{M}_{2}(5,90 \mathrm{~mm})$. Perlakuan pupuk organik cair (POC) berpengaruh tidak nyata terhadap diameter batang bibit sawit dimana perlakuan tertinggi $\mathrm{P}_{0}(6,49 \mathrm{~mm})$ diikuti $\mathrm{P}_{2}(6,22 \mathrm{~mm}), \mathrm{P}_{1}(6.08 \mathrm{~mm})$ dan $\mathrm{P}_{3}(5,87 \mathrm{~mm})$. Interaksi perlakuan media tanam dan pupuk organik cair berpengaruh tidak nyata terhadap diameter batang bibit sawit dengan perlakuan tertinggi $\mathrm{M}_{1} \mathrm{P}_{1}(6,97 \mathrm{~mm})$.

\section{Bobot Basah (g)}

Hasil sidik ragam diperoleh bahwa perlakuan media tanam dan pupuk organik cair serta interaksi keduanya berpengaruh tidak nyata terhadap bobot basah bibit sawit (Tabel 4).

Tabel 4. Hubungan bobot basah dengan interaksi perlakuan ragam media tanam dan pupuk organik cair pada tanaman kelapa sawit umur 11 MST.

\begin{tabular}{cccccc}
\hline Perlakuan & $\mathrm{P}_{0}$ & $\mathrm{P}_{1}$ & $\mathrm{P}_{2}$ & $\mathrm{P}_{3}$ & Rataan \\
\hline $\mathrm{M}_{0}$ & 10,06 & 10,42 & 9,78 & 11,22 & 10,37 \\
$\mathrm{M}_{1}$ & 10,04 & 10,34 & 10,72 & 10,68 & 10,45 \\
$\mathrm{M}_{2}$ & 8,79 & 10,39 & 9,23 & 9,86 & 9,57 \\
\hline Rataan & 9,63 & 10,38 & 9,91 & 10,58 & \\
\hline
\end{tabular}

Keterangan: angka-angka yang diikuti huruf yang sama pada baris atau kolom yang sama menujukkan berbeda tidak nyata pada taraf 5\% menggunakan DMRT.

Pada Tabel 4, dapat dilihat bahwa perlakuan media tanam berpengaruh tidak nyata terhadap bobot 
basah bibit sawit dimana perlakuan tertinggi $\mathrm{M}_{1}(10,45 \mathrm{~g})$ diikuti $\mathrm{M}_{0}(10,37 \mathrm{~g})$ dan $\mathrm{M}_{2}(9,57 \mathrm{~g})$. Perlakuan pupuk organik cair (POC) berpengaruh tidak nyata terhadap bobot basah bibit sawit dimana perlakuan tertinggi $\mathrm{P}_{3}$ $(10,58 \mathrm{~g})$ diikuti $\mathrm{P}_{1}(10,38 \mathrm{~g}), \mathrm{P}_{2}(9,91 \mathrm{~g})$ dan $\mathrm{P}_{0}(9,63 \mathrm{~g})$. Interaksi perlakuan media tanam dan pupuk organik cair berpengaruh tidak nyata terhadap bobot basah bibit sawit dengan perlakuan tertinggi $\mathrm{M}_{0} \mathrm{P}_{3}(11,22 \mathrm{~g})$.

\section{Bobot Kering (g)}

Hasil sidik ragam diperoleh bahwa perlakuan media tanam dan pupuk organik cair serta interaksi keduanya berpengaruh tidak nyata terhadap bobot kering bibit sawit (Tabel 5).

Tabel 5. Hubungan bobot kering dengan interaksi perlakuan ragam media tanam dan pupuk organik cair pada tanaman kelapa sawit umur 11 MST.

\begin{tabular}{cccccc}
\hline Perlakuan & $\mathrm{P}_{0}$ & $\mathrm{P}_{1}$ & $\mathrm{P}_{2}$ & $\mathrm{P}_{3}$ & Rataan \\
\hline $\mathrm{M}_{0}$ & 2,65 & 2,50 & 2,58 & 2,95 & 2,67 \\
$\mathrm{M}_{1}$ & 2,64 & 2,72 & 2,82 & 2,81 & 2,75 \\
$\mathrm{M}_{2}$ & 2,58 & 2,75 & 2,70 & 2,60 & 2,66 \\
\hline Rataan & 2,62 & 2,66 & 2,70 & 2,79 &
\end{tabular}

Keterangan: angka-angka yang diikuti huruf yang sama pada baris atau kolom yang sama menujukkan berbeda tidak nyata pada taraf 5\% menggunakan DMRT.

Pada Tabel 5, dapat dilihat bahwa perlakuan media tanam berpengaruh tidak nyata terhadap bobot kering bibit sawit dimana perlakuan tertinggi $\mathrm{M}_{1}(2,75 \mathrm{~g})$ diikuti $\mathrm{M}_{0}(2,67 \mathrm{~g})$ dan $\mathrm{M}_{2}(2,66 \mathrm{~g})$. Perlakuan pupuk organik cair (POC) berpengaruh tidak nyata terhadap bobot kering bibit sawit dimana perlakuan tertinggi $\mathrm{P}_{3}$ $(2,79 \mathrm{~g})$ diikuti $\mathrm{P}_{2}(2,70 \mathrm{~g}), \mathrm{P}_{1}(2,66 \mathrm{~g})$ dan $\mathrm{P}_{0}(2,62 \mathrm{~g})$. Interaksi perlakuan media tanam dan pupuk organik cair berpengaruh tidak nyata terhadap bobot kering bibit sawit dengan perlakuan tertinggi $\mathrm{M}_{0} \mathrm{P}_{3}(2,95 \mathrm{~g})$.

\section{Pengaruh ragam media tanam terhadap pertumbuhan vegetatif bibit kelapa sawit di pembibitan awal}

Hasil penelitian dapat dilihat bahwa pemberian perlakuan dengan ragam media tanam berpengaruh tidak nyata terhadap tinggi tanaman, diameter batang, bobot basah dan bobot kering namun berpengaruh nyata terhadap luas daun bibit sawit. Hal ini disebabkan karena ragam media tanam tidak mampu mempengaruhi pertumbuhan tanaman bibit kelapa sawit tersebut, pada lampiran analisis sebelum tanam dapat dilihat bahwa unsur hara yang terdapat pada media tanam tersebut sangat rendah, Pada lampiran analisa media tanam umur 11 MST terjadi penambahan atau kenaikan unsur hara dalam media tanam namun tidak telalu signifikan sehingga tidak mempengaruhi pertumbuhan. Leiwakabessy, (1997) mengatakan bahwa pertumbuhan dan perkembangan tanaman sangat dipengaruhi oleh unsur hara yang tersedia pertumbuhan akan maksimum jika unsur hara yang tersedia dalam keadaan optimum dan seimbang. Menurut Sarief (1985), mengemukakan bahwa untuk tanaman tahunan, penambahan jumlah daun dan luas daun membutuhkan unsur hara yang seimbang dan berlanjut dalam waktu yang cukup lama.
Pengaruh pupuk organik cair terhadap pertumbuhan vegetatif bibit kelapa sawit di pembibitan awal

Hasil penelitian dapat dilihat bahwa pemberian perlakuan pupuk organik (POC) berpengaruh tidak nyata terhadap tinggi tanaman, diameter batang, bobot basah dan bobot kering bibit sawit dan berpengaruh nyata terhadap luas daun. Hal ini disebabkan bahwa pemberian POC tidak mampu menambah hara organik pada media tanam. Menurut Puspadewi et al., (2014) pemberian POC secara tunggal menghasilkan pertumbuhan dan hasil tanaman yang kurang baik karena nilai hara yang terdapat pada POC sangat rendah sehingga penyerapan unsur hara oleh tanaman juga tidak optimal.

Interaksi ragam media dan pupuk organik cair terhadap pertumbuhan vegetatif bibit kelapa sawit di pembibitan awal

Interaksi media tanam dan pupuk organik cair berpengaruh tidak nyata terhadap tinggi tanaman, diameter batang, bobot basah dan bobot kering sedangkan pada parameter luas daun berpengaruh nyata. Hal ini disebabkan karena perlakuan yang diberikan belum mampu mempengaruhi pola aktivitas fisiologi tanaman walaupun diantara perlakuan yang diuji telah mampu mendukung pertumbuhan tanaman secara fisiologi.

Adapun hal lain yang menyebabkan tidak adanya pengaruh yang nyata terhadap seluruh parameter yang diamati diduga interaksi kedua perlakuan kurang saling mendukung satu sama lainnya, sehingga efeknya akar tanaman tidak respon dan ini sesuai dengan pendapat Hakim et al., (1986) menyatakan bahwa pertumbuhan tanaman yang baik dapat tercapai bila faktor yang mempengaruhi pertumbuhan berimbang dan menguntungkan.

\section{KESIMPULAN}

Perlakuan media tanam, pupuk organik cair (POC) serta interaksi kedua faktor tersebut berpengaruh tidak nyata terhadap tinggi tanaman, diameter batang, bobot basah dan bobot kering tanaman namun berpengaruh nyata terhadap luas daun tanaman. Perlakuan $\mathrm{M}_{1} \mathrm{P}_{1}$ (pupuk kandang ayam $30 \%+$ abu sekam padi $30 \%+$ topsoil $40 \%$ dan pupuk organik cair (POC) $10 \mathrm{ml} / \mathrm{l}$ air) dapat dilakukan dalam budidaya kelapa sawit di prenursery

\section{DAFTAR PUSTAKA}

Gomez, K. A. dan A. A. Gomez. 2007. Prosedur Statistika untuk Penelitian Pertanian. Terjemahan : Sjamsudin, E dan J. S. Baharsyah. UI-Press.

Hakim, N, M, Y. Nyakpa, A, M. Lubis, S.G. Nugroho, M.K. Saul, M.H. Diha, G.B. Hong dan H. H. Bailey. 1986. Dasar-Dasar Ilmu Tanah. Unila. Lampung.

Hantu, J., 2013. POC. Hantu Jantan. www. Jimmyhantu.com. Diakses tanggal 28 Mei 2015.

Kusmarwiyah, E. dan Erni, S. 2011. Pengaruh Media Tumbuh dan pupuk Organik Cair Terhadap Pertumbuhan dan hasil Tanaman Seledri (Apium graveolens L.). Crop Agro, Jurnal Ilmiah Budidaya, 
Agrinula : Jurnal Agroteknologi dan Perkebunan Volume 2 Nomor 1 Tahun 2019, hal. 13-16

$4(2), 7-12$.

Lubis, A.U. 1992. Kelapa Sawit (Elaeis guineensi Jacq) di Indonesia. Balai Penelitian Marihat. Sumatera Utara. Hal. 1-393.

Nasaruddin dan Rosmawati. 2011. Pengaruh Pupuk Organik Cair (POC) Hasil Fermentasi Daun Gamal, Batang Pisang dan Sabut Kelapa terhadap pertumbuhan Bibit Kakao. Jurnal Agrisistem, (7)1, 29-37.

Sarief, S. 1985. Konservasi Tanah dan Air. Bandung: Pustaka Buana.

Sastrosayono, S. 2008. Budidaya Kelapa Sawit. AgroMedia Pustaka. Jakarta

Sianturi, H. S. D. 1992. Budidaya Kelapa Sawit. USU Press. Medan.

Sutanto, R. 2006. Penerapan Pertanian Organik. Kanisius. Yogyakarta. Hal.1-210. 